\title{
Effect of maternal ABO blood type on birth weight and preeclampsia
}

\author{
Fatma Beyazit, Eren Pek*, Aysenur Çakır Güngör, Meryem Gencer, Mesut A. Unsal
}

Department of Obstetrics and Gynecology, Canakkale Onsekiz Mart University, Canakkale, Turkey.

Received: 15 April 2017

Accepted: 08 May 2017

\section{*Correspondence:}

Dr. Eren Pek,

E-mail: drerenpek@ hotmail.com

Copyright: (c) the author(s), publisher and licensee Medip Academy. This is an open-access article distributed under the terms of the Creative Commons Attribution Non-Commercial License, which permits unrestricted non-commercial use, distribution, and reproduction in any medium, provided the original work is properly cited.

\begin{abstract}
Background: $\mathrm{ABO}$ blood group has been recognized as a risk factor for distinct disease states. The association between $\mathrm{ABO}$ blood group and adverse pregnancy outcomes has not been extensively studied, especially in relation to birth weight and preeclampsia (PE). The aim of the present study is to determine whether ABO blood group contributes to the adverse pregnancy outcomes including low birth weight and PE.

Methods: Medical data including ABO phenotypes were collected from hospital electronic database and retrospectively reviewed. Adverse pregnancy outcomes included PE and low birth weight. Birth week was also noted for each subject.

Results: 2177 charts of mothers who had given birth in our hospital were studied. Overall $605(27.8 \%)$ women had type O blood, 1056 (48.5\%) had type A blood, 369 (16.9\%) had type B blood and 147 (6.8\%) had type AB blood. Pregnant women with type B blood group had significantly lower birth weights compared with type O, A and AB. Birth weeks of all groups were found to be similar with no statistically significant difference. A total of 167 mothers were recorded as having PE. No association was observed between PE and ABO blood groups of study participants. Conclusions: Although maternal ABO phenotype is associated with low birth weight, no association was found between blood type and preeclampsia. We postulate that maternal/fetal immune system genes which are directly associated with $\mathrm{ABO}$ blood groups could affect pregnant with a resulting birth weight alterations.
\end{abstract}

Keywords: ABO blood type, Birth weight, Pregnancy, Preeclampsia

\section{INTRODUCTION}

Various studies have shown a strong association between ABO blood groups and increased susceptibility to certain disease conditions including cardiovascular events, viral or bacterial infections, colorectal cancer, intracranial aneurysm and thromboembolic diseases. ${ }^{1-4}$ Moreover, the relation between $\mathrm{ABO}$ blood type and adverse pregnancy outcomes has also been reported in literature including preeclampsia (PE), chorioamnionitis, venous thromboembolism and post-partum haemorrhage. ${ }^{5}$ Unfortunately, controversies have arisen among these studies that have reported a possible relation between blood types and pregnancy outcomes.
ABO blood group antigens (namely, A, B, AB and O) which have been discovered nearly a century ago is expressed on the surface of a wide range of human cells and tissues. 5,6 The blood group of a person depends upon the presence or absence of two genes A and B. Both the $A$ and $B$ alleles encode slightly different versions of the enzyme glycosyltransferases that produce both A and B antigens. The $\mathrm{O}$ allele encodes an inactive glycosyltransferase that leaves the $\mathrm{ABO}$ antigen precursor unmodified. These antigens exist in different cell and tissue systems including red blood cells (RBC), vascular endothelium, epidermis, platelets, and neurons. ${ }^{7,8}$ Because of this wide range of expression, ABO blood group antigens constitute an intriguing field 
of research outside the area of transfusion and transplantation medicine including the area of reproductive medicine. In this context, PE is the most studied disease condition that is accused to be associated with ABO blood type. Preliminary studies suggest that ABO blood type of pregnant women is an independent risk factor for adverse pregnancy outcomes. Unfortunately, the relationship between $\mathrm{ABO}$ blood groups and $\mathrm{PE}$ which has been observed in many studies for years resulted in conflicting conclusions. ${ }^{9,10}$

Adverse pregnancy complications including PE, preterm birth and delivery of low birth weight (LBW) babies represent a major global public health concern. Although these complications generally depend upon the underlying maternal medical conditions such as poorly controlled blood pressure and diabetes, fetal and placental factors can also be responsible from this fetal complication. ${ }^{11}$ In this context, LBW is one of the most intractable and yet clinically relevant complication affecting human pregnancies with an increased neonatal mortality and morbidity rates. Regardless of gestational age, LBW is defined as a birth weight of a liveborn infant of $2500 \mathrm{~g}$ or less. LBW babies are significantly at risk of death, contributing to the high perinatal morbidity and mortality. ${ }^{12}$ Despite a great number of risk factors that is known to be associated with LBW, in $40 \%$ of cases the exact mechanisms causing LBW are not known. ${ }^{13}$ Based on the association between $\mathrm{ABO}$ blood group and adverse pregnancy outcomes, we hypothesized that blood group antigens may be responsible for the pathogenesis of LBW babies. Therefore, the goal of this study was to evaluate ABO blood types with some common adverse pregnancy events including PE, LBW and preterm delivery.

\section{METHODS}

This retrospective study was conducted in the Department of Obstetrics and Gynecology at Çanakkale 18 Mart University, Turkey. After the approval from the same university's Institutional Ethics Board, we used the hospital's electronic database which contains multiple data fields on demographic and clinical variables for both mothers and neonates. We retrospectively analyzed 2177 women who had given birth in our hospital between November 2012 and December 2016. Only mothers with documented $\mathrm{ABO}$ blood group was included in the present study. Women having a history of any drug use (except for vitamins, iron and folate), multi-fetal pregnancy, erythroblastosis fetalis were excluded from the study.

$\mathrm{PE}$ is defined as gestational hypertension with proteinuria. Regardless of gestational age, LBW was defined as weight at birth $<2500 \mathrm{~g}$, up to and including $2499 \mathrm{~g}$. The gestational age at birth was classified as term ( $\geq 37$ weeks) and preterm $(\leq 36+6$ weeks). Statistical analysis was done with SPPS version 19 (SPSS Inc., Chicago, IL, USA). Continuous variables were given as mean \pm standard deviation; categorical variables were defined as percentages. Qualitative variables are given as percent. A P-value below 0.05 was considered significant.

\section{RESULTS}

A total of 2177 pregnant women included in the present study. Mean age of study participants were 28.8 \pm 5.4 . Mean age of the study participants according to ABO blood groups are presented in Table 1. The most common blood type detected in our study group was type A (48.5\%) (Table 1).

Table 1: ABO blood types of study participants.

\begin{tabular}{|llll|}
\hline Blood type & Mean age (years) & n & $\%$ \\
\hline O+ & $28.9 \pm 5.1$ & 543 & 24.9 \\
\hline O- & $29.1 \pm 6.1$ & 62 & 2.8 \\
\hline $\mathrm{A}+$ & $28.9 \pm 5.4$ & 958 & 44.0 \\
\hline $\mathrm{A}-$ & $28.8 \pm 5.5$ & 98 & 4.5 \\
\hline $\mathrm{B}+$ & $28.5 \pm 5.3$ & 274 & 12.6 \\
\hline $\mathrm{B}-$ & $29.2 \pm 6.1$ & 95 & 4.6 \\
\hline $\mathrm{AB}+$ & $28.2 \pm 5.7$ & 128 & 5.8 \\
\hline AB- & $29.1 \pm 6.1$ & 19 & 0.8 \\
\hline Total & & 2177 & 100 \\
\hline
\end{tabular}

605 out of 2177 pregnants had type O blood, 1056 had type A blood, 369 had type B blood and 147 had type AB blood. Mean birth weight and birth week of pregnant women are given in Table 2. Pregnant women with type B blood group had significantly lower birth weights compared with type $\mathrm{O}, \mathrm{A}$ and $\mathrm{AB}$. Birth weeks of all groups were found to be similar with no statistically significant difference (Table 2).

Table 2: Birth week, birth weight and presence of preeclampsia according to blood groups.

\begin{tabular}{|llllll|} 
& Blood groujps & & & & \\
& $\mathbf{O}(\mathbf{n}=\mathbf{6 0 5})$ & $\mathbf{A}(\mathbf{n}=\mathbf{1 0 5 6})$ & $\mathbf{B}(\mathbf{n = 3 6 9})$ & $\mathbf{A B}(\mathbf{n = 1 4 7 )}$ & $\mathbf{p}$ \\
\hline Birth weight (gram) & $3294 \pm 562$ & $3137 \pm 543$ & $3005 \pm 571$ & $3127 \pm 489$ & $<0.001^{*}$ \\
\hline Birth week & $38.5 \pm 1.8$ & $38.3 \pm 1.9$ & $38.1 \pm 2.6$ & $38.3 \pm 1.7$ & NS \\
\hline Preeclampsia & & & & & NS \\
\hline Yes (n, \%) & $48(7.9)$ & $71(6.7)$ & $35(9.4)$ & $13(8.8)$ & \\
\hline No (n, \%) & $547(94.9)$ & $985(93.3)$ & $338(90.6)$ & $134(91.2)$ & \\
\hline
\end{tabular}

*B blood type versus $\mathrm{O}, \mathrm{A}$ and $\mathrm{AB}$ blood type. 
A total of $167(7.6 \%)$ mothers were recorded as having PE. According to the blood groups, $7.9 \%$ pregnants with O group, $6.7 \%$ pregnants with A group, $9.4 \%$ pregnants with B group and $8.8 \%$ pregnants with $\mathrm{O}$ group had PE (table 2). PE rates were similar in four distinct blood groups $(\mathrm{p}=0.876)($ Table 2$)$.

$6.9 \%$ pregnants with $\mathrm{O}$ group, $10.1 \%$ pregnants with $\mathrm{A}$ group, $17.1 \%$ pregnants with $\mathrm{B}$ group and $10.2 \%$ pregnants with AB group had LBW babies. (Table 3). LBW babies were significantly higher in mothers with $B$ blood group $(\mathrm{p}<0.005)$.

Table 3: Low birth weight babies (<2500 gram) according to maternal ABO blood group.

\begin{tabular}{|l|lll|}
\hline \multirow{4}{*}{$\begin{array}{l}\text { Blood group } \\
\text { Low birth }\end{array}$} & $\mathrm{O}$ & $42 / 605$ & $\%$ \\
\hline weight & $\mathrm{A}$ & $107 / 1056$ & 10.1 \\
\hline & $\mathrm{B}$ & $63 / 369$ & 17.1 \\
\hline & $\mathrm{AB}$ & $15 / 147$ & 10.2 \\
\hline
\end{tabular}

\section{DISCUSSION}

Several lines of evidence had previously suggested a possible association between $\mathrm{ABO}$ blood group and risk of adverse pregnancy outcomes including PE, chorioamnionitis, and venous thromboembolism. .,6,14 $^{\text {and }}$ Despite potential pathophysiological mechanisms and pathways which have been put forward to explain these associations, many conflicting results still awaits resolution. This study is performed in order to understand the existing body of knowledge and to fill the gap in this area.

The main finding of the present study is to show that type B blood group is associated with LBW in pregnant women with no associated disease. Although no literature data exists regarding the association between $\mathrm{ABO}$ blood groups and birth weight, it is believed that $\mathrm{ABO}$ blood group antigens attached to cell surface glycoconjugates play many important roles in immune and coagulation systems. ${ }^{15}$ Moreover, particular combinations of maternal/fetal immune system genes which are directly associated with $\mathrm{ABO}$ blood groups could affect pregnants with a resulting birth weight alterations. In addition, fetal growth in uterus partially depends on the maternal blood supply to the placenta which necessitates structural modifications of the uterine spiral arteries. ${ }^{16}$ Therefore, the causative role of non-O blood type in arterial thrombosis may put a pregnant at a specific risk according to her inherited blood group antigens during pregnancy. In this study, we observed that $7.9 \%$ pregnants with $\mathrm{O}$ group, $6.7 \%$ pregnants with A group, 9.4\% pregnants with $\mathrm{B}$ group and $8.8 \%$ pregnants with $\mathrm{O}$ group had PE. Although there was no significant association between ABO blood group and PE, several studies have convincingly proven that the ABO blood type could play a partial role in the pathogenesis of PE. ${ }^{14,17}$ The most plausible factor linking PE to ABO blood type is the existence of a prothrombotic state especially in cases with non-O blood groups. Women with $\mathrm{AB}$ blood group have elevated plasma levels of coagulation factors including factor VIII and von Willebrand factor (vWF), triggering or worsening the pathophysiologic events that lead to PE. One other mechanism linking ABO blood group to PE seems to be maternal immune response related to placental protein 13 (PP13) which differentially binds to erythrocytes from distinct $\mathrm{ABO}$ groups, with strongest binding to blood group $\mathrm{AB} .{ }^{15,18}$ In the first trimester, reduced expression of PP13 in placenta may contribute to the early pathogenetic events in the placental microenvironment leading to PE.

Although various studies have examined a causal relationship between maternal $\mathrm{ABO}$ antigens and preeclampsia, there is still no consensus on whether a true association does exist. In a recent study by Phaloprakarn and Tangjitgamol, it was found that women with $\mathrm{A}$ or $\mathrm{AB}$ blood types, but not $\mathrm{B}$, were at increased risk of $\mathrm{PE}$ compared with $\mathrm{O}$ type individuals. ${ }^{9}$ Similarly, Spinillo and colleagues and Hiltunen and colleagues showed that $\mathrm{PE}$ risk was increased by 2.1- to 3.1-fold in Italian and Finnish gravidas with $\mathrm{AB}$ blood group compared to that in pregnant women with $\mathrm{O}$ blood group. ${ }^{19,20}$ Contrary to these reports Hentschke et al demonstrated that there were no association between blood groups and the development of PE. ${ }^{21}$ In overall with so many variables and conflicting results, it is difficult to draw a definitive conclusion regarding a probable association between ABO blood types and PE.

We recognize some limitations of this analysis. Firstly, this is a retrospective study which includes a cohort from a single academic center. Second, we didn't analyse the association between ABO blood group and other adverse pregnancy outcomes such as chorioamnionitis, venous thromboembolism and gestational diabetes mellitus. And finally, missing data in this retrospective study may have weakened the association of the variables examined in this study.

\section{CONCLUSION}

In conclusion, we have demonstrated a potential association between $\mathrm{ABO}$ blood groups and birth weight which needs to be further investigated by prospective randomized trials.

\section{Funding: No funding sources \\ Conflict of interest: None declared \\ Ethical approval: The study was approved by the Institutional Ethics Committee}

\section{REFERENCES}

1. Shavakhi A, Hajalikhani M, Minakari M, Norian A, Riahi R, Azarnia M, et al. The association of non-O blood group and severity of liver fibrosis in patients 
with chronic hepatitis C infection. J Res Med Sci. 2012;17(5):466-9.

2. Khalili H, Wolpin BM, Huang ES, Giovannucci EL, Kraft P, Fuchs CS, et al. ABO blood group and risk of colorectal cancer. Cancer Epidemiol Biomarkers Prev. 2011;20(5):1017-20.

3. Bir SC, Bollam P, Nanda A. Distribution of ABO blood groups in the patients with intracranial aneurysm and association of different risk factors with particular blood type. Asian J Neurosurg. 2015;10(3):153-7.

4. Wu O, Bayoumi N, Vickers MA, Clark P. ABO(H) blood groups and vascular disease: a systematic review and meta-analysis. J Thromb Haemost. 2008;6(1):62-9.

5. Franchini M, Mengoli C, Lippi G. Relationship between $\mathrm{ABO}$ blood group and pregnancy complications: a systematic literature analysis. Blood Transfus. 2016;14(5):441-8.

6. Hosoi E. Biological and clinical aspects of ABO blood group system. J Med Invest. 2008;55(34):174-82.

7. Dentali F, Sironi AP, Ageno W, Crestani S, Franchini M. ABO blood group and vascular disease: an update. Semin Thromb Hemost. 2014;40(1):4959.

8. Franchini M, Lippi G. The intriguing relationship between the $\mathrm{ABO}$ blood group, cardiovascular disease, and cancer. BMC Med. 2015;13:7.

9. Phaloprakarn C, Tangjitgamol S. Maternal ABO blood group and adverse pregnancy outcomes. J Perinatol. 2013;33(2):107-11.

10. Seyfizadeh N, Seyfizadeh N, Yousefi B, Borzoueisileh S, Majidinia M, Shanehbandi D, et al. Is there association between $\mathrm{ABO}$ blood group and the risk factors of unfavorable outcomes of pregnancy? J Matern Fetal Neonat Med. 2015;28(5):578-82.

11. Barden A. Pre-eclampsia: contribution of maternal constitutional factors and the consequences for cardiovascular health. Clin Exp Pharmacol Physiol. 2006;33(9):826-30.

12. Shinwell ES. Neonatal morbidity of very low birth weight infants from multiple pregnancies. Obstet Gynecol Clin North Am. 2005;32(1):29-38.

13. Khan NS, Ashraf RN, Noor S, Rahman M, Mashhadi $\mathrm{SF}$, Rashid Z, et al. Association of Maternal
Periodontitis with Low Birth Weight in Newborns in a Tertiary Care Hospital. J Ayub Med Coll Abbottabad. 2016;28(1):120-5.

14. Alpoim PN, de Barros PM, Junqueira DR, Freitas LG, das Graças CM, Fernandes AP, et al. Preeclampsia and ABO blood groups: a systematic review and meta-analysis. Mol Biol Rep. 2013;40(3):2253-61.

15. Mital P, Gupta D, Benwal DK, Gangwal H, Hooja N, Agarwal S, et al. To find any association of maternal blood group as a risk factor for preeclampsia Int $\mathbf{J}$ Comm Med Public Health. 2016;3(12):3445-9.

16. Hiby SE, Apps R, Chazara O, Farrell LE, Magnus P, Trogstad L, et al. Maternal KIR in combination with paternal HLA-C2 regulate human birth weight. J Immunol. 2014;192(11):5069-73.

17. Clark P, Walker ID, Govan L, Wu O, Greer IA. The GOAL study: a prospective examination of the impact of factor $\mathrm{V}$ Leiden and $\mathrm{ABO}(\mathrm{H})$ blood groups on haemorrhagic and thrombotic pregnancy outcomes. Br J Haematol. 2008;140(2):236-40.

18. Avci D, Karagoz H, Ozer O, Esmeray K, Bulut K, Aykas F, et al. Are the blood groups of women with preeclampsia a risk factor for the development of hypertension postpartum? Therap Clin Risk Manag. 2016;12:617-22.

19. Spinillo A, Capuzzo E, Baltaro F, Piazzi G, Iasci A. Case-control study of maternal blood group and severe pre-eclampsia. J Hum Hypertens. 1995;9(8):623-5.

20. Hiltunen LM, Laivuori H, Rautanen A, Kaaja R, Kere J, Krusius T, et al. Blood group AB and factor $\mathrm{V}$ Leiden as risk factors for pre-eclampsia: a population-based nested case-control study. Thromb Res. 2009;124(2):167-73.

21. Hentschke MR, Caruso FB, Paula LG, Medeiros AK, Gadonski G, Antonello IC, et al. Is there any relationship between $\mathrm{ABO} / \mathrm{Rh}$ blood group and patients with pre-eclampsia? Pregnancy Hypertens. 2014;4(2):170-3.

Cite this article as: Beyazit F, Pek E, Güngör CA, Gencer M, Unsal MA. Effect of maternal ABO blood type on birth weight and preeclampsia. Int J Reprod Contracept Obstet Gynecol 2017;6:2164-7. 